\title{
Analysis of volatile organic compounds released from human lung cancer cells and from the urine of tumor-bearing mice
}

\author{
Yosuke Hanai ${ }^{1 *}$, Ken Shimono ${ }^{2}$, Hiroaki Oka ${ }^{2}$, Yoshinobu Baba ${ }^{1,3}$, Kunio Yamazaki ${ }^{4}$ and Gary K Beauchamp ${ }^{4}$
}

\begin{abstract}
Backgrounds: A potential strategy for the diagnosis of lung cancer is to exploit the distinct metabolic signature of this disease by way of biomarkers found in different sample types. In this study, we investigated whether specific volatile organic compounds (VOCs) could be detected in the culture medium of the lung cancer cell line A549 in addition to the urine of mice implanted with A549 cells.

Results: Several VOCs were found at significantly increased or decreased concentrations in the headspace of the A549 cell culture medium as compared with the culture medium of two normal lung cell lines. We also analyzed the urine of mice implanted with A549 cells and several VOCs were also found to be significantly increased or decreased relative to urine obtained from control mice. It was also revealed that seven VOCs were found at increased concentrations in both sample types. These compounds were found to be dimethyl succinate, 2pentanone, phenol, 2-methylpyrazine, 2-hexanone, 2-butanone and acetophenone.
\end{abstract}

Conclusions: Both sample types produce distinct biomarker profiles, and VOCs have potential to distinguish between true- and false-positive screens for lung cancer.

Keywords: Lung cancer, VOCs, GC-TOF MS, Cell medium, Urine, Tumor-bearing mice

\section{Background}

A 2008 report issued by the WHO [1], estimates that about $18 \%$ of all of cancer deaths can be attributed to lung cancer. Annually, lung cancer accounts for about 1.3 million deaths worldwide. For this reason, the development of a novel diagnostic test, which can facilitate the early detection of lung cancer, has the ability to vastly reduce lung cancer mortality rates. Although many studies report the utility of diagnostic imaging such as X-ray and CT scan, these modalities are both expensive and susceptible to false positive and false negative results.

The ability to combine imaging techniques with other methodologies such as biomarkers is a strategy with the potential to enhance the detection of lung cancer [2-4]. Although various biomarkers from blood, saliva and

\footnotetext{
* Correspondence: hanai.yosuke@kk.jp.panasonic.com

${ }^{1}$ FRIST Research Center for Innovative Nanobiodevice, Nagoya University,

Nagoya 464-8603, Japan

Full list of author information is available at the end of the article
}

urine have been detected, including proteins, tumor antigens, anti-tumor antibodies, cell type-specific peptides, metabolic products and epigenetic phenomena such as hyper-methylated DNA, RNA, and the expression of specific genes [5], to date none of these biomarkers has had the adequate sensitivity, specificity and reproducibility to be considered for use clinically.

The analysis of exhaled breath for endogenous volatile organic compounds (VOCs) is one possible example of a non-invasive diagnostic assay that can be applied to cancer patients [6-9]. Current examples include the ${ }^{13} \mathrm{C}$ urea breath test for the detection of Helicobacter pylori $[10,11]$, and the hydrogen-based breath test for carbohydrate malabsorption [12]. Another example is acetone, which is found at increased concentrations in the exhaled breath of patients with uncontrolled diabetes mellitus [13].

Sulfur-containing compounds such as ethylmercaptane, dimethylsulfide and dimethyldisulfide contribute to the characteristic odor of patients with liver cirrhosis
C Biomed Central

(c) 2012 Hanai et al; licensee BioMed Central Ltd. This is an Open Access article distributed under the terms of the Creative Commons Attribution License (http://creativecommons.org/licenses/by/2.0), which permits unrestricted use, distribution, and reproduction in any medium, provided the original work is properly cited. 
[14]. In contrast, nitrogen-containing compounds are typical of patients suffering from uremia [15]. Ethane and pentane increase in concentration alongside the concentration of lipid peroxidation $[16,17]$.

Several studies have shown that potential biomarkers for lung cancer are low molecular weight VOCs, which can be detected in the breath of lung cancer patients [18-24]. For example, a recent study using solid phase micro-extraction followed by gas chromatography showed that 1-butanol and 3-hydroxy-2-butanone is found at significantly higher concentrations in the breath of lung cancer patients compared with the control group [25]. Dragonieri et al. reported the use of an "electronic nose" which was able to discriminate between patients with lung cancer versus those with chronic obstructive lung disease (COPD) with a relatively high degree of sensitivity and specificity [26].

In addition to exhaled breath, urine is also considered to be a potential source of VOCs. However, one issue associated with the analysis of urine is the potential that VOCs detected in urine samples are derived from exogenous sources such as diet or the environment rather than as a result of the disease. For instance, Willis et al. reported that dogs could be trained to distinguish patients with bladder cancer on the basis of urine odor [27]. However, a follow-up study was unable to reproduce these findings in urine samples from patients with breast and prostate cancer [28]. Matsumura et al. also reported that sensor mice could be trained to discriminate between mice with and without tumors demonstrating that volatile odorants can be used to identify tumor-bearing mice [29]. Thus, there is mounting evidence that clinically relevant biomarkers for cancer may be found in urine.

Nevertheless, the cellular and biochemical origin of endogenous VOCs that have potential as lung cancer biomarkers are not well understood. A number of articles have investigated the release of VOCs from human cancer cells in vitro [25,30-32]. In the human lung carcinoma cell CALU-1, the release of branched hydrocarbons such as 2,3,3-trimethylpentane, 2,3,5trimethylhexane, 2,4-dimethylheptane and 4-methyloctane were all found to be increased, whereas levels of acetaldehyde, 3-methylbutanal, $n$-butyl acetate, acetonitrile, acrolein, methacrolein, 2-methylpropanal, 2-butanone, methyl tert-butyl ether and hexanal were all decreased [31]. In the human lung cancer cell line NCIH2087, alcohol 2-ethyl-1-hexanol and alkane 2-methylpentane were found at increased concentrations, compared with acetaldehyde, 2-methylpropanal, 3methylbutanal, 2-methylbutanal and $n$-butyl acetate concentration which were found to be decreased [32]. While it has been reported that there may be a correlation between the VOCs detected in cell culture medium and in exhaled breath [25], no VOCs common to both urine and cell culture medium have been detected.

In the present study, we compared the VOCs released from the human lung adenocarcinoma cell line A549 to two normal lung cell lines, OUS-11 and WI-38 VA1 to determine whether any cancer specific compounds could be detected. We also investigated whether urine specific VOCs could be used to distinguish between tumor-bearing mice and healthy control mice, and whether there were any common compounds detected in both sample types.

\section{Result}

\section{Comparative analysis of VOCs in the human lung cancer} and normal lung cell lines

To extract the VOCs, upon reaching confluency the cell lines were grown for one, two and three weeks. After a one week incubation period, no dead cells were observed in any of the cell lines. After two week, some floating cells were observed and the culture medium had turned red (all cell lines). After the three week incubation period, many floating cells were observed and in all cell lines the culture medium was becoming amber. Thus, the culture conditions of the one and two week incubation periods ensured that the release of VOCs into the medium was mostly due to living cells. However, following three week incubation, cell viability diminished, indicating that released VOCs were not derived from the living cells. Typical total ion chromatograms (TICs) of VOCs measured in the medium samples of each cell line after one week incubation are shown in Figure 1. A sample of media obtained from the A549 cell lines showed a peak at 12.82 min that was clearly increased when compared with the control cell lines. However, the measured TICs were difficult to analyze because of multiple ion peaks, making it difficult to find the different EIC peaks in each of the cell lines. To analyze in more detail, comparative analysis between the A549 cell line and control cell lines was performed using XCMS software [33] and statistical analyses. Under our experimental conditions, an average of 751 ion peaks per sample was detected in the culture medium by XCMS software and statistical analyses. The significantly increased or decreased ion peaks (with a $p$ value $<0.10$ and 1.5 -fold higher or lower than average peak area of the normal control) were selected for identification. These ion peaks were summarized by deconvolution analysis of retention time and identified by spectral library match using the NIST'08 and Wiley library. However, identification of the VOCs was done only by means of spectral library matching (higher than $80 \%$ match) without confirmation of their retention times and comparison against a commercially available standard reagent. In this study, any peaks that could not 


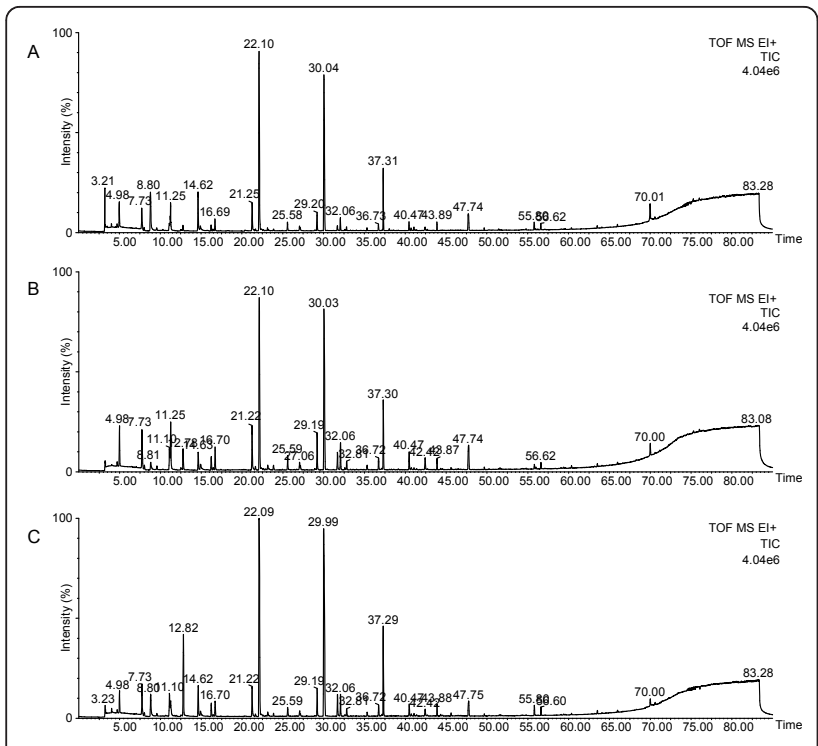

Figure 1 Typical TIC of the VOCs from the culture medium samples of WI-38 VA13 cells (A), OUS-11 cells (B) and A549 cells (C) after 1-week incubation. The TICs were obtained from analysis of the samples (200 $\mu \mathrm{L}$ ) by HS-SPME (DVB/CAR/PDMS, 50/30 $\mu \mathrm{m}, 2 \mathrm{~cm}$ ) and GC-TOF MS. The extraction temperature was $45^{\circ} \mathrm{C}$ and the time was 50 min. Desorption was performed at $240^{\circ} \mathrm{C}$ for $10 \mathrm{~min}$. The injection was pulsed splitless (closed $3 \mathrm{~min}$ ) with a 0.75 $\mathrm{mm}$ liner. Temperature programming consisted of an initial temperature $40^{\circ} \mathrm{C}$ for $5 \mathrm{~min}$, followed by $3^{\circ} \mathrm{C} / \mathrm{min}$ to $240^{\circ} \mathrm{C}$ with a 5 min hold at this final temperature. The other GC-MS conditions are described in the Material and Methods.

be determined due to too low a library match were disregarded. The summary of determined VOCs by XCMS analysis are listed in Table 1, which also shows the rate of change with averaged peak area (using major $\mathrm{m} / z$ ), comparing between the A549 and control cells. After a one week incubation period, there was a difference in the concentration of 31 compounds in the A549 cells compared with the control cells, whereby 18 compounds were found to be significant increased and 13 compounds were found to be significantly decreased ( $p<$ 0.10 ) (Table 1A). After a two week incubation period differences in the concentration of 45 compounds between the A549 and control cells culture medium were detected whereby 31 compounds were significantly increased, and 14 compounds were significantly decreased $(p<0.10)$ (Table 1B). After the three week incubation different concentrations were observed in 30 compounds, whereby 28 compounds were significant increased, and two compounds were significant decreased $(p<0.10)$ (Table 1C).

\section{Preparation of the human lung cancer mouse model}

To observe the proliferation of the A549 cells implanted into the mice, tumor size was measured (Figure 2a), with measurement commencing at day 13 post implantation. The body weight of the mice was also recorded (Figure 2b). Although there was a slight decrease in body weight in the two days following transplantation, this then gradually increased over subsequent days. There was no significant difference in body weight between the tumor-bearing and control mice.

\section{Comparative analysis of VOCs from the urine of tumor- bearing and control mice}

The pooled urine samples from the tumor-bearing $(\mathrm{n}=$ $24)$ and control $(n=16)$ mice were analyzed by headspace solid-phase microextraction (HS-SPME) and gas chromatography time-of-flight mass spectrometry (GCTOF MS). Two typical TICs of the VOCs obtained from the urine samples are shown in Figure 3. The chromatographs obtained from urine samples were very similar to the cultured medium samples, making it difficult to identify differences between peaks in EICs of the tumorbearing and control mice. However, the results obtained from detailed and comparative analyses of the two groups did reveal some differences. On average the chromatogram from each urine sample contained 1493 ion peaks and from this 68 ion peaks were significantly increased and 65 ion peaks were decreased relative to the control group $(p<0.10$ and characterized by a 1.5fold higher or lower than average peak area of the control). Deconvolution analysis of the retention time of each peak allowed for the isolation of 76 VOCs that were significantly increased and six VOCs that were decreased. The isolated VOCs were picked up by similarity searching using the mass spectral library (NIST'08 and Wiley). Any VOC that could not be determined because a library match is too low was disregarded. Table 2 shows the 43 VOCs that were found be highly similar following a search of the database. However, these VOCs were identified only by means of spectral library match (higher than $80 \%$ match) without confirmation of their retention times and mass spectral by comparison against a commercially available standard reagent. Moreover, Table 2 shows the rate of change with averaged peak area (using major $m / z$ ), comparing between the tumor-bearing and control mice. In the urine obtained from the tumor-bearing mice, the concentration of 43 compounds was different relative to the control group $(p<0.10)$, whereby 42 compounds were significantly increased, and one compound was significantly decreased.

\section{Seven VOCs were increased in both the A549 cell medium and urine from tumor-bearing mice}

We also investigated the compounds in more detail that were increased in both the one and two week culture medium samples (A549 cells), and urine of the tumorbearing mice. Seven compounds were increased in all 
Table 1 List of the VOCs obtained from the culture medium of A549 cell line that were increased or decreased

\begin{tabular}{|c|c|c|c|c|}
\hline A & & & & \\
\hline Increased compound & CAS No. & Classification & fold & $p$-value \\
\hline 1-Dodecanol & $112-53-8$ & alcohols & ++ & $<0.01$ \\
\hline 1-Methoxy-2-propanol & $107-98-2$ & ethers & +++ & 0.02 \\
\hline 2,2,4-Trimethyl-1,3-pentanediol diisobutyrate & $6846-50-0$ & esters & + & 0.09 \\
\hline 2,5-Hexanedione & $110-13-4$ & ketones & + & 0.08 \\
\hline 2-Butanone & $78-93-3$ & ketones & + & 0.06 \\
\hline 2-Phenyl-2-propanol & $617-94-7$ & alcohols & +++ & 0.02 \\
\hline 3,3,5-Trimethylcyclohexanone & $873-94-9$ & ketones & ++ & 0.04 \\
\hline 3-Butene-2-one & $78-94-4$ & ketones & + & 0.03 \\
\hline 4-Cyanocyclohexene & $100-45-8$ & nitriles & + & 0.07 \\
\hline Acetonitrile & $75-05-8$ & nitriles & + & 0.03 \\
\hline Cyclohexanone & $108-94-1$ & ketones & + & 0.04 \\
\hline Diethyl ether & $60-29-7$ & ethers & ++ & $<0.01$ \\
\hline Dimethyl succinate & $106-65-0$ & esters & ++ & 0.06 \\
\hline Ethanol & $64-17-5$ & alcohols & +++ & 0.01 \\
\hline Isobutyric acid 2-ethyl-3-hydroxyhexyl ester & $74367-31-0$ & esters & + & $<0.01$ \\
\hline Isophorone & $78-59-1$ & ketones & ++ & 0.02 \\
\hline Orthoformic acid tri-sec-butyl ester & $16754-48-6$ & esters & +++ & 0.02 \\
\hline tert-Butanol & $75-65-0$ & alcohols & + & $<0.01$ \\
\hline Decreased compound & CAS No. & Classification & fold & $p$-value \\
\hline 1,3-Di-tert-butylbenzene & $1014-60-4$ & hydrocarbons & - & 0.07 \\
\hline 2,4-Dimethyl-1-heptene & $19549-87-2$ & hydrocarbons & - & 0.04 \\
\hline 2,4-Di-tert-butylphenol & $96-76-4$ & phenols & - & 0.06 \\
\hline 2,5-Dimethyl-2,5-hexanediol & $110-03-2$ & alcohols & - & 0.02 \\
\hline 2-Methyl-1-propanol & $78-83-1$ & alcohols & - & 0.06 \\
\hline 4,6-Dimethyl-2-heptanone & 19549-80-5 & ketones & - & 0.05 \\
\hline 5-Methylnonane & $15869-85-9$ & hydrocarbons & - & 0.01 \\
\hline Acetophenone & $98-86-2$ & ketones & - & 0.08 \\
\hline Benzophenone & 119-61-9 & ketones & - & 0.04 \\
\hline Benzyl alcohol & $100-51-6$ & alcohols & - & 0.02 \\
\hline Dichloromethane & $75-09-2$ & halogens & - & $<0.01$ \\
\hline Maltol & 118-71-8 & pyrans & - & $<0.01$ \\
\hline Styrene & $100-42-5$ & hydrocarbons & - & 0.05 \\
\hline \multicolumn{5}{|l|}{ B } \\
\hline Increased compound & CAS No. & Classification & fold & $p$-value \\
\hline 1-Dodecanol & $112-53-8$ & alcohols & +++ & $<0.01$ \\
\hline 2,2,4-Trimethyl-1,3-pentanediol diisobutyrate & $6846-50-0$ & esters & + & 0.03 \\
\hline 2,2,5,5-Tetramethyltetrahydrofuran & $15045-43-9$ & furans & + & $<0.01$ \\
\hline 2,2-Dimethyloxetane & $6245-99-4$ & ethers & + & $<0.01$ \\
\hline 2,3-Dihydro-4-methylfuran & $34314-83-5$ & furans & + & $<0.01$ \\
\hline 2,4,6-Trimethylpyridine & $108-75-8$ & pyridines & + & 0.01 \\
\hline 2,4-Di-tert-butylphenol & $96-76-4$ & phenols & + & 0.01 \\
\hline 2,5-Dimethyl-2,5-hexanediol & $110-03-2$ & diols & + & 0.03 \\
\hline 2-Butanone & $78-93-3$ & ketones & ++ & $<0.01$ \\
\hline 2-Hexanone & $591-78-6$ & ketones & + & 0.04 \\
\hline 2-Methoxyfuran & $25414-22-6$ & furans & + & 0.02 \\
\hline 2-Methyl-1-propanol & $78-83-1$ & alcohols & + & 0.02 \\
\hline 2-Octanone & $111-13-7$ & ketones & + & 0.03 \\
\hline 2-Pentanone & 107-87-9 & ketones & + & $<0.01$ \\
\hline 3-Aminopyrazole-4-carboxylic acid & $24447-68-5$ & carboxylic acids & + & $<0.01$ \\
\hline 3-Methyl-3-buten-1-ol & $763-32-6$ & alcohols & + & 0.01 \\
\hline
\end{tabular}


Table 1 List of the VOCs obtained from the culture medium of A549 cell line that were increased or decreased (Continued)

\begin{tabular}{|c|c|c|c|c|}
\hline 4-Isopropoxy-2-butanone & $32541-58-5$ & ketones & + & 0.02 \\
\hline 4-Methylbenzyl alcohol & $589-18-4$ & alcohols & + & $<0.01$ \\
\hline Acetonylacetone & $110-13-4$ & ketones & ++ & $<0.01$ \\
\hline Acetophenone & $98-86-2$ & ketones & ++ & $<0.01$ \\
\hline Diethyl ether & $60-29-7$ & ethers & ++ & $<0.01$ \\
\hline Dimethyl succinate & $106-65-0$ & esters & +++ & $<0.01$ \\
\hline DL-1-Phenylethyl alcohol & $98-85-1$ & alcohols & + & 0.01 \\
\hline Ethanol & $64-17-5$ & alcohols & ++ & 0.01 \\
\hline Furfural & $98-01-1$ & aldehydes & + & 0.02 \\
\hline Isobutyric acid 2-ethyl-3-hydroxyhexyl ester & $74367-31-0$ & esters & + & 0.01 \\
\hline Methyl vinyl ketone & 78-94-4 & ketones & + & $<0.01$ \\
\hline Orthoformic acid tri-sec-butyl ester & $16754-48-6$ & esters & + & $<0.01$ \\
\hline o-Xylene & $95-47-6$ & hydrocarbons & + & 0.05 \\
\hline Pyrrole & 109-97-7 & pyrroles & ++ & $<0.01$ \\
\hline trans-4-Methyl-2-pentene & $674-76-0$ & hydrocarbons & + & 0.01 \\
\hline Decreased compound & CAS No. & Classification & fold & $p$-value \\
\hline 1,2-Dihydro-2,2,4-trimethylquinoline & $147-47-7$ & quinolines & - & 0.01 \\
\hline 1-Butanol & 71-36-3 & alcohols & - & 0.05 \\
\hline 2,3-Butanediol & $19132-06-0$ & diols & - & $<0.01$ \\
\hline 2-Ethyl-1-hexanol & 104-76-7 & alcohols & - & 0.06 \\
\hline 2-Methyl-2-hepten-6-one & $110-93-0$ & ketones & - & $<0.01$ \\
\hline 3,5-Lutidine & $591-22-0$ & pyridines & - & $<0.01$ \\
\hline Acetonitrile & 75-05-8 & nitriles & - & $<0.01$ \\
\hline Benzophenone & $119-61-9$ & ketones & - & $<0.01$ \\
\hline Cyclohexanone & $108-94-1$ & ketones & - & 0.01 \\
\hline Dimethyl disulfide & $624-92-0$ & Sulfurs & - & 0.09 \\
\hline Isophorone & 78-59-1 & ketones & - & 0.02 \\
\hline Maltol & 118-71-8 & pyrans & - & $<0.01$ \\
\hline Methanethiol & 74-93-1 & thiols & - & 0.1 \\
\hline Tributyl phosphate & $126-73-8$ & esters & - & 0.03 \\
\hline \multicolumn{5}{|l|}{ C } \\
\hline Increased compound & CAS No. & Classification & fold & $p$-value \\
\hline 1,4-Diacetylbenzene & 1009-61-6 & ketones & ++ & $<0.01$ \\
\hline 1-Hydroxycyclohexanecarboxylic acid & $1123-28-0$ & carboxylic acids & +++ & $<0.01$ \\
\hline 2,2,4-Trimethyl-1,3-pentanediol diisobutyrate & $6846-50-0$ & esters & ++ & $<0.01$ \\
\hline 2,4,6-Trimethylpyridine & $108-75-8$ & pyridines & ++ & 0.02 \\
\hline 2,6-Di-tert-butylphenol & $128-39-2$ & phenols & + & 0.08 \\
\hline 2-Butanone & 78-93-3 & ketones & ++ & $<0.01$ \\
\hline 2-Octanone & $111-13-7$ & ketones & + & $<0.01$ \\
\hline 3-Methyl-3-buten-1-ol & $763-32-6$ & alcohols & + & 0.01 \\
\hline 3-Octanol & $589-98-0$ & alcohols & + & 0.01 \\
\hline 4-Cyanocyclohexene & $100-45-8$ & nitriles & + & $<0.01$ \\
\hline 4-Methylbenzyl alcohol & $589-18-4$ & alcohols & ++ & $<0.01$ \\
\hline Acetophenone & $98-86-2$ & ketones & + & $<0.01$ \\
\hline Benzaldehyde & $100-52-7$ & aldehydes & + & 0.07 \\
\hline Benzophenone & 119-61-9 & ketones & +++ & $<0.01$ \\
\hline Benzyl alcohol & $100-51-6$ & alcohols & ++ & $<0.01$ \\
\hline $\begin{array}{l}\text { Bisisobutyric acid } \\
\text { 2,4,4-trimethylpentane-1,3-diyl ester }\end{array}$ & 74381-40-1 & esters & ++ & 0.02 \\
\hline Carbamic acid, 4-methylphenyl ester & 1850-13-1 & esters & +++ & $<0.01$ \\
\hline Cyclohexanone & 108-94-1 & ketones & + & 0.02 \\
\hline
\end{tabular}


Table 1 List of the VOCs obtained from the culture medium of A549 cell line that were increased or decreased (Continued)

\begin{tabular}{|c|c|c|c|c|}
\hline Diethyl ether & $60-29-7$ & ethers & ++ & $<0.01$ \\
\hline Dimethyl succinate & $106-65-0$ & esters & +++ & 0.01 \\
\hline DL-1-Phenylethyl alcohol & $98-85-1$ & alcohols & ++ & $<0.01$ \\
\hline Ethanol & $64-17-5$ & alcohols & ++ & 0.09 \\
\hline Furfural & $98-01-1$ & aldehydes & + & $<0.01$ \\
\hline Isobutyric acid 2-ethyl-3-hydroxyhexyl ester & $74367-31-0$ & esters & ++ & $<0.01$ \\
\hline Phenol & $108-95-2$ & phenols & + & 0.04 \\
\hline p-Tolualdehyde & $104-87-0$ & aldehydes & + & $<0.01$ \\
\hline Pyrrole & 109-97-7 & pyrroles & + & $<0.01$ \\
\hline omega-Caprolactam & $105-60-2$ & amides & ++ & $<0.01$ \\
\hline Decreased compound & CAS No. & Classification & fold & $p$-value \\
\hline 2,4-Dimethyl-1-heptene & $19549-87-2$ & hydrocarbons & - & 0.01 \\
\hline Maltol & $118-71-8$ & pyrans & - & 0.01 \\
\hline
\end{tabular}

A: One week incubation; B: Two week incubation; C: Three week incubation

This table shows the VOCs, which were significantly different $(p<0.10)$ and more than 1.5 fold different to the averaged peak area $(n=3)$. The fold change indicates the difference in the averaged peak area between the A549 human lung cancer cell line and normal lung cells (+++ > 3 fold increase, $++>2$ fold increase, $+>1.5$ fold increase, $-<3$ fold decrease,

$-<2$ fold decrease, $-<1.5$ fold decrease)

three samples. It was also discovered that dimethyl succinate, phenol, 2-methylpyrazine, 2-hexanone, 2-butanone, 2-pentanone and acetophenone could be identified not only by spectral library match using NIST'08 and Wiley library but also by matching with retention time and mass spectral of commercially available reagents (data not shown).

To determine the concentration of the seven VOCs, a standard curve was prepared with analysis by HS-SPME. The standard curves were induced using the peak area at most abundance $m / z$ value. The calibration measurements were used to determine the limit of detection (LOD) and subsequent quantification (LOD) of seven VOCs. Results in Table 3 present the accuracy of the standard curve. The standard curve of each VOC indicated good linearity in the range of $0.02 \mu \mathrm{M}$ to $10 \mu \mathrm{M}$ $\left(\mathrm{R}^{2}=0.99\right)$. The concentration of each VOCs was then calculated using the respective standard curves. The quantitative findings, with accompanying statistical analysis, are summarized in Tables 4 and 5 (cell cultures) and Table 6 (mice urine). The significance of the results was calculated by ANOVA.

Summary of the concentration and significant difference of seven VOCs in culture medium were shown in Tables 4 and 5. After one week incubation, five VOCs in A549 cell medium were significantly increased (2-butanone, 2-pentanone, dimethyl succinate, acetophenone, phenol), 2methylpyrazine was significantly decreased in comparison to the VOCs in the DMEM. Four VOCs in A549 cell medium were significantly increased in comparison to the VOCs in OUS-11 cell medium; 2-butanone ( $p=0.001)$, 2pentanone $(p=0.015), 2$-methylpyrazine $(p=0.012)$, dimethyl succinate $(p=0.023)$. Five VOCs in A549 cell medium were significantly increased in comparison to the VOCs in WI-38 VA13 cell medium; 2-pentanone ( $p=$ $0.001), 2$-hexanone $(p=0.002)$, dimethyl succinate $(p=$ $0.016)$, acetophenone $(p=0.001)$, phenol $(p=0.011)$. After two week incubation, five VOCs in A549 cell medium were significantly increased (2-butanone, 2-pentanone, dimethyl succinate, acetophenone, phenol), 2-methylpyrazine was significantly decreased in comparison to VOCs in the DMEM. All seven VOCs in A549 cell medium were significantly increased in comparison to the VOCs in OUS-11 cell medium; 2-butanone ( $p<0.001)$, 2-pentanone $(p<0.001), 2$-hexanone $(p=0.008), 2$-methylpyrazine $(p<0.001)$, dimethyl succinate $(p<0.001)$, acetphenone $(p<0.001)$ and phenol $(p=0.001)$. Five VOCs in A549 cell medium were significantly increased in comparison to the VOCs in WI-38 VA13 cell medium; 2butanone $(p=0.001), 2$-pentanone $(p=0.001)$, 2-hexanone $(p=0.039)$, dimethyl succinate $(p<0.001)$, acetphenone $(p<0.001)$.

Summary of the concentration and significant difference of all seven VOCs in mice urine was shown in Table 6. All VOCs were significantly increased in tumor-bearing mice urine in comparison to the VOCs in control mice urine; 2-butanone $(p=0.02), 2$-pentanone $(p=0.08), 2$-hexanone $(p=0.02)$, 2-methylpyrazine $(p=0.03)$, dimethyl succinate $(p=0.03)$, acetphenone $(p=0.02)$ and phenol $(p=0.01)$.

\section{Discussion}

The ability to use the VOCs detected in the urine of patients with lung cancer as putative tumor markers 


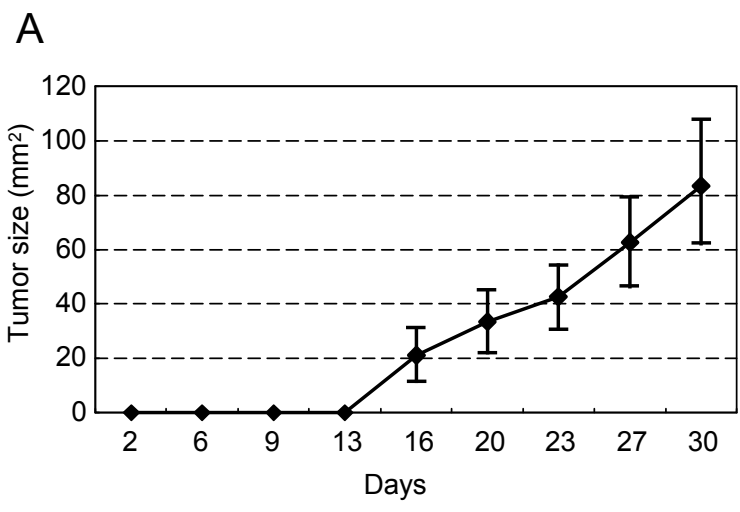

B

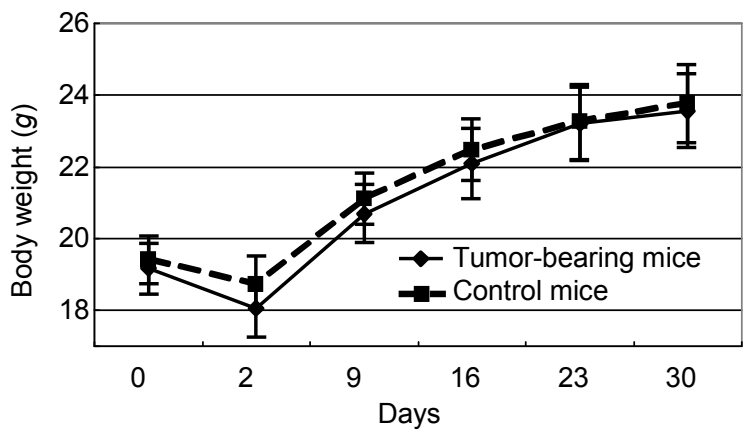

Figure 2 Tumor measurement and animal body weight in the lung cancer animal model. (A) Average tumor size in the tumorbearing mice. Tumor size was calculated by multiplying the shortest and longest diameters using digital calipers. (B) The body weight of the tumor-bearing (solid line) and control mice (dash line). Each data point indicates an average value with standard deviation. The days indicate the number of days after transplantation. Body weight and tumor size of each mouse was recorded every few days.

may facilitate the rapid detection and non-invasive diagnosis of lung cancer. In this study, we identified VOCs derived from three cell lines (A549, OUS-11, WI-38 VA13) and from the urine of mice inoculated with the A549 human tumor cell line. The compounds were detected by HS-SPME and analyzed by GC-MS. The SPME method is simple and highly sensitive, and the in this study we used a SPME fiber (2 cm divinylbenzene/ carboxen/polydimethylsiloxane: DVB/CAR/PDMS) which was the most absorbent as shown by the number of peaks which we were able to detect. Using this fiber, we analyzed the substances contained in the headspace of each sample.

Several studies have also reported that VOCs are associated with lung cancer $[18,20-24]$. For most of these VOCs however, the cancer cells from which they are derived and their biochemical origins were not determined, allowing for the possibility that they are

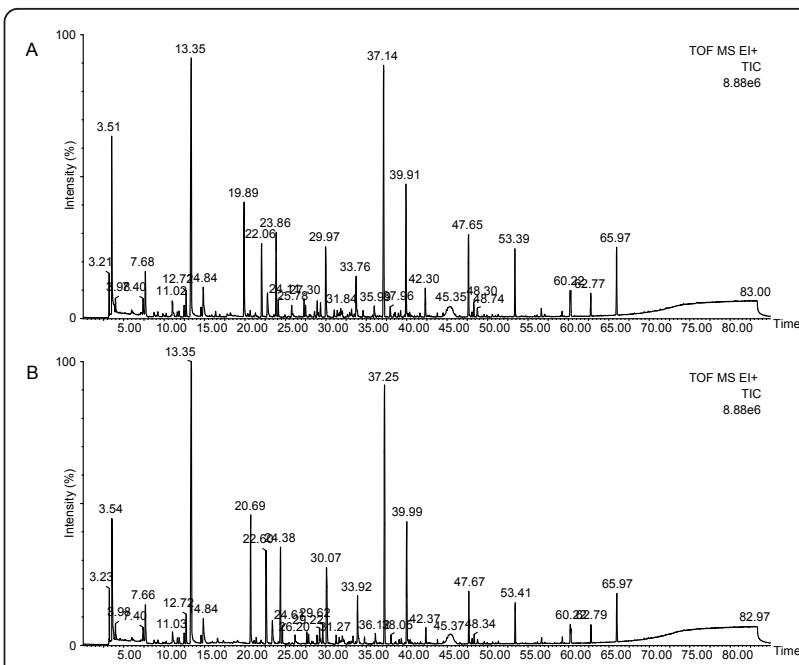

Figure 3 Typical TIC of the VOCs from the urine samples obtained from the tumor-bearing (A) and normal control mice (B). The TIC was obtained from the analysis of urine samples (200 $\mu \mathrm{L}$ ) by HS-SPME (DVB/CAR/PDMS, 50/30 $\mu \mathrm{m}, 2 \mathrm{~cm}$ ) and GC-TOF MS. The extraction temperature was $45^{\circ} \mathrm{C}$ and the time was 50 min. Desorption was performed at $240^{\circ} \mathrm{C}$ for $10 \mathrm{~min}$. The injection was pulsed splitless (closed $3 \mathrm{~min}$ ) with a $0.75 \mathrm{~mm}$ liner. Temperature programming was set at an initial temperature of $40^{\circ} \mathrm{C}$ for $5 \mathrm{~min}$, then programmed at $3^{\circ} \mathrm{C} / \mathrm{min}$ to $240^{\circ} \mathrm{C}$ with a 5 min hold at this final temperature. All other GC-MS conditions are described in the Material and Methods.

exogenous substances. In this study, we searched for characteristic compounds derived from lung cancer cells by comparing the VOCs from lung cancer cells (A549) and non-tumor cells. Under our experimental conditions, the composition of the detected VOCs was different for each cell and further varied according to incubation period. Moreover, it was found that 18 (one week incubation), 31 (two week incubation) and 28 compounds (three week incubation) were increased in the culture medium of A549 cells compared with nontumor cells. These compounds mostly consisted of ketones and alcohols. In the case of the one week incubation group, alcohols (1-methoxy-2-propanol, 2-phenyl-2-propanol and ethanol) were significantly increased, compared with the control cells. The two week incubation caused an increase in the concentration of 1-dodecanol and dimethyl succinate. In the case of the cells incubated for three week the concentration of 1-hydroxycyclohexanecarboxylic acid, benzophenone, carbamic acid 4-methylphenyl ester and dimethyl succinate were all increased. However, at the three week incubation period, many dead cells were observed and the color of medium was becoming amber, meaning that the VOCs obtained from this experimental group may not reflect VOCs derived from living cells. Ten of the VOCs in the one week and two week incubation period were found to be common to both groups: dimethyl succinate, 
Table 2 List of the VOCs obtained from the tumorbearing mice that were increased or decreased relative to the control group.

\begin{tabular}{|c|c|c|c|c|}
\hline Increased compound & CAS No. & Classification & fold & $\begin{array}{c}p- \\
\text { value }\end{array}$ \\
\hline 1,3-Di-tert-butylbenzene & $1014-60-4$ & ethers & + & 0.08 \\
\hline $\begin{array}{l}\text { 2-(sec-butyl)-4,5- } \\
\text { dihydrothiazole }\end{array}$ & $\begin{array}{c}56367-27- \\
2\end{array}$ & sulfurs & ++ & 0.01 \\
\hline 2,4-Dimethylheptane & $2213-23-2$ & hydrocarbons & + & $<0.01$ \\
\hline 2,5-Dimethylpyrazine & $123-32-0$ & pyrazines & + & 0.07 \\
\hline 2,5-Heptanedione & $1703-51-1$ & ketones & + & 0.03 \\
\hline 2-Acetyl-5-methylfuran & 1193-79-9 & furans & + & 0.02 \\
\hline 2-Aminobenzamide & $88-68-6$ & aldehydes & + & 0.05 \\
\hline 2-Butanone & $78-93-3$ & ketones & + & 0.02 \\
\hline 2-Ethyl-5-methylfuran & $1703-52-2$ & furans & + & 0.06 \\
\hline 2-Heptanone & $110-43-0$ & ketones & + & 0.04 \\
\hline 2-Hexanone & $591-78-6$ & ketones & + & 0.03 \\
\hline $\begin{array}{l}\text { 2-Methoxy-5- } \\
\text { methylthiophene }\end{array}$ & $\begin{array}{c}31053-55- \\
1\end{array}$ & sulfurs & + & 0.02 \\
\hline 2-Methylfuran & $534-22-5$ & furans & ++ & 0.01 \\
\hline 2-Methylpyrazine & 109-08-0 & pyrazines & ++ & 0.07 \\
\hline 2-Pentanone & $107-87-9$ & ketones & + & 0.09 \\
\hline 2-Methyl-6-vinylpyrazine & $\begin{array}{c}13925-09- \\
2\end{array}$ & pyrazines & ++ & 0.02 \\
\hline 3-Hexanone & $589-38-8$ & ketones & + & 0.1 \\
\hline 3-Methyl-1-hexen-3-ol & $\begin{array}{l}55145-28- \\
3\end{array}$ & alcohols & ++ & 0.01 \\
\hline 4-Heptanone & 123-19-3 & ketones & + & 0.03 \\
\hline 4-Ketoisophorone & $1125-21-9$ & ketones & + & 0.05 \\
\hline 4-Methoxyphenol & $150-76-5$ & phenols & + & 0.02 \\
\hline 4-Methyloctane & $2216-34-4$ & hydrocarbons & + & 0.02 \\
\hline 5-Hepten-2-one & $6714-00-7$ & ketones & + & 0.04 \\
\hline 6-methyl-3-heptanone & $624-42-0$ & ketones & + & 0.03 \\
\hline Acetone & $67-64-1$ & ketones & + & 0.03 \\
\hline Acetophenone & $98-86-2$ & ketones & + & 0.03 \\
\hline Benzaldehyde & $100-52-7$ & aldehydes & + & 0.03 \\
\hline Dimethyl succinate & $106-65-0$ & esters & + & 0.05 \\
\hline Dimethyl trisulfide & $3658-80-8$ & sulfurs & + & 0.04 \\
\hline Dimethylamine & $124-40-3$ & amines & $\begin{array}{c}++ \\
+\end{array}$ & 0.1 \\
\hline exo-Brevicomin & $\begin{array}{l}20290-99- \\
7\end{array}$ & ethers & + & 0.03 \\
\hline gamma-Crotonolactone & $497-23-4$ & esters & + & 0.05 \\
\hline gamma-Hexanolactone & 695-06-7 & esters & + & 0.02 \\
\hline Maltol & $118-71-8$ & pyrans & + & 0.02 \\
\hline N,N-Dimethylacetamide & $127-19-5$ & amines & + & 0.08 \\
\hline N-Benzylidenemethylamine & $622-29-7$ & amines & $\begin{array}{c}++ \\
+\end{array}$ & 0.06 \\
\hline Phenol & $108-95-2$ & phenols & + & 0.01 \\
\hline Phenylacetone & 103-79-7 & ketones & + & 0.07 \\
\hline p-Toluidine & $106-49-0$ & amines & + & 0.03 \\
\hline Pyrazinamide & $98-96-4$ & amides & + & 0.01 \\
\hline Quinazoline & $253-82-7$ & Quinazolines & $\begin{array}{c}++ \\
+\end{array}$ & 0.07 \\
\hline Trimethylamine & $75-50-3$ & amines & + & 0.02 \\
\hline
\end{tabular}

Table 2 List of the VOCs obtained from the tumor-bearing mice that were increased or decreased relative to the control group. (Continued)

\begin{tabular}{|c|c|c|c|c|}
\hline Decreased compound & CAS No. & Classification & fold & $p$-value \\
\hline 4-Met & 8 & & - & $<0.0$ \\
\hline \multicolumn{5}{|c|}{$\begin{array}{l}\text { ble shows the VOCs, which were significantly different }(p<0.10) \text { and } \\
\text { han } 1.5 \text { fold different to the averaged peak area }(n=3) \text {. The fold } \\
\text { indicates the difference in the averaged peak area between the } \\
\text { bearing mice and normal control mice }(+++>3 \text { fold increase, }++>2 \\
\text { crease, }+>1.5 \text { fold increase, }-<3 \text { fold decrease, }-<2 \text { fold decrease }\end{array}$} \\
\hline
\end{tabular}

diethyl ether, ethanol, 2,2,4-trimethyl-1,3-pentanediol diisobutyrate, isobutyric acid 2-ethyl-3-hydroxyhexyl ester, 2-butanone, 1-dodecanol, 3-butene-2-one, orthoformic acid tri-sec-butyl ester and 2,5-hexanedione. These include the plasticizer-like compounds (e.g. 2,2,4Trimethyl-1,3-pentanediol diisobutyrate). Thus, it is necessary to consider the possibility that exogenous compounds were also detected. Filipiak et al. also reported that the concentration of ethanol was significantly increased in A549 cells, although this finding was made under different experiment conditions [34]. However, some of the VOCs identified in cultured medium of the A549 cells differ from the compounds reported by Filipiak. The culture conditions and extraction methods (thermal desorption vs solid-phase microextraction) may be responsible for this difference. It has also been reported that 2-butanone was increased in the cultured medium of NCI-H2087 and CALU-1 lung cancer cell lines, although not at remarkably high levels [31,32]. Additionally, Sponring et al. has also suggested that 2butanone may be increased in the breath of lung cancer patients [32]. The reason for the differences in the release or consumption of VOCs among the investigated cell lines is currently unknown, but may result from phenotypic or genotypic differences. The differences may also reflect the characteristics of the specific cell lines tested.

We created a mouse model of human lung cancer, and analyzed the VOCs obtained from the urine of these mice. When the urinary VOCs of the tumor-bearing mice were compared with of the control group differences in 43 compounds was observed (42 were increased and one was decreased). Matsumura et al. created a mouse lung cancer model, and identified the characteristics of some VOCs from the urine of these animals, including that 2-heptanone, 5-heptene-2-one were able to distinguish between the lung cancer group and the control group [29]. According to our results, 2-heptanone and 5-heptene-2-one were identified as being significantly increased in the urine of the lung cancer group. 
Table 3 Summary of common VOCs from cells and mice

\begin{tabular}{|c|c|c|c|c|c|c|c|c|}
\hline Compound & CAS & classification & $\begin{array}{l}\text { Retention time of standard } \\
\text { (min) }\end{array}$ & $\begin{array}{c}\text { Quantified ion } \\
(m / z)\end{array}$ & $\begin{array}{c}\text { Range of calibration } \\
(\mu \mathrm{M})\end{array}$ & $\mathrm{R}^{2}$ & $\begin{array}{l}\text { LOD } \\
(\mu \mathrm{M})\end{array}$ & $\begin{array}{l}\mathrm{LOQ} \\
(\mu \mathrm{M})\end{array}$ \\
\hline 2-Butanone & $78-93-3$ & ketones & 10.5 & 72 & $0.1-10$ & 0.992 & 0.058 & 0.176 \\
\hline 2-Pentanone & $\begin{array}{l}107-87- \\
9\end{array}$ & ketones & 14.7 & 86 & $0.02-10$ & 0.999 & 0.006 & 0.017 \\
\hline 2-Hexanone & $\begin{array}{l}591-78- \\
\quad 6\end{array}$ & ketones & 19.8 & 100 & $0.1-10$ & 1.000 & 0.014 & 0.042 \\
\hline $\begin{array}{c}2- \\
\text { Methylpyrazine }\end{array}$ & $\begin{array}{l}109-08- \\
0\end{array}$ & pyrazines & 27.0 & 94 & $0.05-10$ & 1.000 & 0.004 & 0.013 \\
\hline $\begin{array}{l}\text { Dimethyl } \\
\text { Succinate }\end{array}$ & $\begin{array}{c}106-65- \\
0\end{array}$ & esters & 36.3 & 115 & $0.1-10$ & 1.000 & 0.014 & 0.043 \\
\hline Acetophenone & $98-86-2$ & ketones & 38.1 & 105 & $0.02-10$ & 1.000 & 0.033 & 0.101 \\
\hline Phenol & $\begin{array}{c}108-95- \\
2\end{array}$ & phenols & 45.6 & 94 & $0.1-10$ & 1.000 & 0.011 & 0.033 \\
\hline
\end{tabular}

Calibration were performed, giving the calibration curve, the limit of detection (LOD) and limit of quantitation (LOQ)

We also found that seven VOCs (dimethyl succinate, 2-pentanone, phenol, 2-methylpyrazine, 2-hexanone, 2butanone, acetophenone) were increased in both the urine of the tumor-bearing mice and the culture medium of the A549 cells. These compounds were identified not only by spectral library matching with NIST'08 and the Wiley library but also by matching the retention times and mass spectrum of commercially available reagents. However, with respect to which culture period is the optimal condition with which to compare with the in vivo model, it is difficult to nominate a culture period that closely mimics the characteristics of the cancer cells in the mice 26-30 days after transplantation. The conditions of the two week culture period are expected to be similar to the tumor-bearing mice, based on the idea that it takes a few days from seeding the cells until they are confluent. 2-Butanone, 2-pentanone, dimethyl succinate, and acetophenone in A549 culture medium were significantly increased in comparison to other samples including DMEM only. So these five VOCs considered suitable candidates for cancer biomarkers. Since 2methylpyrazine and 2-hexanone are not likely to be released from A549 cancer cell, we currently made a conclusion to discard these compounds from candidates for biomarker. O'Nell et al. reported that 2-butanone and acetophenone can be detected in the exhaled breath of lung cancer patients [35]. It has also been reported that benzaldehyde, 2-butanone and acetophenone are three of the compounds identified as potential breath markers for lung cancer, in a test which has $80 \%$ sensitivity and $100 \%$ specificity for the diagnosis of lung cancer [36].

Based on the results obtained from this study, it could be also suggested that some of the VOCs unique to lung cancer may also be detected in urine. Our results provide preliminary evidence that urinary biomarkers may also represent a feasible method for the early detection and non-invasive diagnosis of lung cancer.

Table 4 Summary of VOCs detected in headspace of culture medium after one week incubation

\begin{tabular}{|c|c|c|c|c|c|c|c|c|c|c|c|c|c|c|}
\hline \multirow[t]{2}{*}{ Compound } & \multicolumn{2}{|c|}{ OUS-11-1w } & \multicolumn{2}{|c|}{$\begin{array}{c}\text { WI-38 VA13- } \\
1 \mathrm{w}\end{array}$} & \multicolumn{2}{|c|}{ DMEM } & \multicolumn{2}{|c|}{ A549-1w } & \multicolumn{2}{|c|}{ A549 vs. OUS-11 } & \multicolumn{2}{|c|}{$\begin{array}{c}\text { A549 vs. WI-38 } \\
\text { VA13 }\end{array}$} & \multicolumn{2}{|c|}{ A549 vs. DMEM } \\
\hline & $\begin{array}{c}\text { Average } \\
(\mu \mathrm{M})\end{array}$ & SD & $\begin{array}{c}\text { Average } \\
(\mu \mathrm{M})\end{array}$ & SD & $\begin{array}{c}\text { Average } \\
(\mu \mathrm{M})\end{array}$ & SD & $\begin{array}{c}\text { Average } \\
(\mu \mathrm{M})\end{array}$ & SD & $\begin{array}{c}p \text {-value } \\
\text { (ANOVA) }\end{array}$ & $\begin{array}{c}\text { Ratio } \\
\text { (A549/ } \\
\text { OUS- } \\
11)\end{array}$ & $\begin{array}{c}p \text {-value } \\
\text { (ANOVA) }\end{array}$ & $\begin{array}{l}\text { Ratio } \\
\text { (A549/ } \\
\text { WI-38 } \\
\text { VA13) }\end{array}$ & $\begin{array}{c}p \text {-value } \\
\text { (ANOVA) }\end{array}$ & $\begin{array}{c}\text { Ratio } \\
\text { (A549/ } \\
\text { DMEM) }\end{array}$ \\
\hline 2-Butanone & 4.656 & 0.165 & 13.826 & 0.945 & 0.554 & 0.104 & 13.418 & 1.452 & 0.001 & 2.9 & 0.756 & 1.0 & $<0.001$ & 24.2 \\
\hline 2-Pentanone & 0.220 & 0.030 & 0.384 & 0.006 & 0.048 & 0.003 & 0.312 & 0.010 & 0.015 & 1.4 & 0.001 & 0.8 & $<0.001$ & 6.4 \\
\hline 2-Hexanone & 0.034 & 0.001 & 0.043 & 0.002 & 0.035 & 0.002 & 0.033 & 0.001 & 0.256 & 1.0 & 0.002 & 0.8 & 0.284 & 0.9 \\
\hline$\stackrel{2-}{2-}$ & $<\mathrm{LOD}$ & & 0.004 & 0.000 & 0.016 & 0.003 & 0.004 & 0.001 & 0.012 & - & 0.337 & 0.9 & 0.004 & 0.2 \\
\hline $\begin{array}{l}\text { Dimethyl } \\
\text { Succinate }\end{array}$ & 0.046 & 0.001 & 0.045 & 0.001 & $<L O D$ & & 0.055 & 0.004 & 0.023 & 1.2 & 0.016 & 1.2 & $<0.001$ & - \\
\hline Acetophenone & 0.403 & 0.026 & 0.647 & 0.019 & $<\mathrm{LOD}$ & & 0.465 & 0.020 & 0.055 & 1.2 & 0.001 & 0.7 & $<0.001$ & - \\
\hline Phenol & 0.099 & 0.002 & 0.160 & 0.003 & 0.041 & 0.001 & 0.095 & 0.020 & 0.835 & 1.0 & 0.011 & 0.6 & 0.019 & 2.3 \\
\hline
\end{tabular}


Table 5 Summary of VOCs detected in headspace of culture medium after two week incubation

\begin{tabular}{|c|c|c|c|c|c|c|c|c|c|c|c|c|c|c|}
\hline \multirow[t]{2}{*}{ Compound } & \multicolumn{2}{|c|}{ OUS-11-2w } & \multicolumn{2}{|c|}{$\begin{array}{c}\text { WI-38 VA13- } \\
2 w\end{array}$} & \multicolumn{2}{|c|}{ DMEM } & \multicolumn{2}{|c|}{ A549-2w } & \multicolumn{2}{|c|}{ A549 vs. OUS-11 } & \multicolumn{2}{|c|}{$\begin{array}{c}\text { A549 vs. WI-38 } \\
\text { VA13 }\end{array}$} & \multicolumn{2}{|c|}{ A549 vs. DMEM } \\
\hline & $\begin{array}{c}\text { Average } \\
(\mu \mathrm{M})\end{array}$ & SD & $\begin{array}{c}\text { Average } \\
(\mu \mathrm{M})\end{array}$ & SD & $\begin{array}{c}\text { Average } \\
(\mu \mathrm{M})\end{array}$ & SD & $\begin{array}{c}\text { Average } \\
(\mu \mathrm{M})\end{array}$ & SD & $\begin{array}{c}p \text {-value } \\
\text { (ANOVA) }\end{array}$ & $\begin{array}{c}\text { Ratio } \\
\text { (A549/ } \\
\text { OUS- } \\
11 \text { ) }\end{array}$ & $\begin{array}{c}p \text {-value } \\
\text { (ANOVA) }\end{array}$ & $\begin{array}{c}\text { Ratio } \\
\text { (A549/ } \\
\text { WI-38 } \\
\text { VA13) }\end{array}$ & $\begin{array}{c}p \text {-value } \\
\text { (ANOVA) }\end{array}$ & $\begin{array}{c}\text { Ratio } \\
\text { (A549/ } \\
\text { DMEM) }\end{array}$ \\
\hline 2-Butanone & 4.293 & 0.184 & 8.971 & 0.761 & 0.767 & 0.120 & 14.616 & 0.570 & $<0.001$ & 3.4 & 0.001 & 1.6 & $<0.001$ & 19.1 \\
\hline 2-Pentanone & 0.158 & 0.003 & 0.203 & 0.024 & 0.031 & 0.002 & 0.363 & 0.016 & $<0.001$ & 2.3 & 0.001 & 1.8 & $<0.001$ & 11.6 \\
\hline 2-Hexanone & 0.030 & 0.000 & 0.033 & 0.000 & 0.034 & 0.002 & 0.037 & 0.002 & 0.008 & 1.2 & 0.039 & 1.1 & 0.150 & 1.1 \\
\hline$\stackrel{2-}{2-}$ & $<\mathrm{LOD}$ & & 0.004 & 0.001 & 0.015 & 0.003 & 0.004 & 0.000 & $<0.001$ & - & 0.750 & 1.0 & 0.005 & 0.3 \\
\hline $\begin{array}{l}\text { Dimethyl } \\
\text { Succinate }\end{array}$ & 0.043 & 0.000 & $<\mathrm{LOD}$ & & $<\mathrm{LOD}$ & & 0.052 & 0.001 & $<0.001$ & 1.2 & $<0.001$ & - & $<0.001$ & - \\
\hline Acetophenone & 0.245 & 0.004 & 0.311 & 0.015 & $<\mathrm{LOD}$ & & 0.561 & 0.015 & $<0.001$ & 2.3 & $<0.001$ & 1.8 & $<0.001$ & - \\
\hline Phenol & 0.077 & 0.006 & 0.120 & 0.005 & 0.031 & 0.001 & 0.129 & 0.005 & 0.001 & 1.7 & 0.144 & 1.1 & $<0.001$ & 4.1 \\
\hline
\end{tabular}

The VOC concentrations are shown with standard deviations. The $p$-values were calculated by ANOVA. The ratio is a comparison of average concentrations of A549 and each samples

\section{Methods}

\section{Cell lines and culturing}

Three different human cell lines were used in the experiments: A549 (JCRB No. JCRB0076), OUS-11 (JCRB No. JCRB1034), WI-38 VA13 (JCRB No. JCRB9057). The A549 cells were originally isolated from a lung carcinoma of a 58-y-old man and are characterized by the presence of a mutated K-ras but a wild-type B-raf gene. The OUS-11 and WI-38 VA13 cells were used as normal control cells for the purposes of comparison and were derived from normal tissue of lung cancer patient and from a SV40 virus transformed lung fibroblast cell line, respectively. The cell lines were obtained from the Health Science Research Resource Bank (Osaka, Japan). All cells have grown in DMEM high-glucose culture medium (Sigma-Aldrich Japan, Tokyo) supplemented with $10 \%$ fetal bovine serum (HyClone, Logan, UT), penicillin (30 unit/mL, Meiji Seika, Tokyo, Japan) and streptomycin $(30 \mu \mathrm{g} / \mathrm{mL}$, Meiji Seika, Tokyo, Japan). The cells were cultured in two culture dishes $(100 \mathrm{~mm} \times 20 \mathrm{~mm})$ in $10 \mathrm{~mL}$ culture medium and every three days fresh medium was applied. For all experiments, the cells were cultured under standard conditions at $37^{\circ} \mathrm{C}$ in humidified atmosphere containing $5 \% \mathrm{CO}_{2}$. For the VOC measurements, the A549, OUS-11 and WI-38 VA13 cells were incubated for one, two and three-weeks after all cell lines grew as monolayer adherent on the surface of culture dishes. After this incubation period, the culture medium was collected and stored at $-80^{\circ} \mathrm{C}$ until analysis.

\section{Tumor model mice of A549 cell line and collection of urine}

Five-week-old female C.B-17/lcr-scidJcl mice (CLEA Japan, Tokyo, Japan) were separated into two groups, those bearing tumors ( $\mathrm{n}=24)$ and those used as controls $(\mathrm{n}=16)$. To establish the human tumor-bearing model, A549 cancer cells were prepared at a concentration of $1.0 \times 10^{8}$ cells $/ \mathrm{mL}$ in PBS, and implanted subcutaneously into the right ventral flank area by injecting $0.1 \mathrm{~mL}$ of the suspension. The control mice were injected only with $0.1 \mathrm{~mL}$ PBS on the same position as

Table 6 Summary of VOCs detected in headspace of mice urine

\begin{tabular}{|c|c|c|c|c|c|c|c|c|}
\hline \multirow[t]{2}{*}{ Compound } & \multirow[t]{2}{*}{ CAS } & \multirow{2}{*}{$\begin{array}{l}\text { Retention } \\
\text { time (min) }\end{array}$} & \multicolumn{2}{|c|}{ control mice } & \multicolumn{2}{|c|}{ tumor-bearing mice } & \multirow{2}{*}{$\begin{array}{c}p \text {-value } \\
\text { (ANOVA) }\end{array}$} & \multirow{2}{*}{$\begin{array}{c}\text { Ratio } \\
\text { (tumor/control) }\end{array}$} \\
\hline & & & $\begin{array}{c}\text { Average } \\
(\mu \mathrm{M})\end{array}$ & SD & $\begin{array}{c}\text { Average } \\
(\mu \mathrm{M})\end{array}$ & SD & & \\
\hline 2-Butanone & $78-93-3$ & 10.5 & 8.808 & 1.154 & 13.226 & 1.297 & 0.02 & 1.5 \\
\hline 2-Pentanone & $107-87-9$ & 14.7 & 2.180 & 0.209 & 2.599 & 0.142 & 0.08 & 1.2 \\
\hline 2-Hexanone & $591-78-6$ & 19.8 & 0.085 & 0.016 & 0.134 & 0.010 & 0.02 & 1.6 \\
\hline 2-Methylpyrazine & 109-08-0 & 27.0 & 0.201 & 0.029 & 0.455 & 0.109 & 0.03 & 2.3 \\
\hline Dimethyl Succinate & $106-65-0$ & 36.3 & 0.237 & 0.017 & 0.334 & 0.038 & 0.03 & 1.4 \\
\hline Acetophenone & $98-86-2$ & 38.1 & 2.310 & 0.499 & 3.912 & 0.399 & 0.02 & 1.7 \\
\hline Phenol & $108-95-2$ & 45.6 & 1.824 & 0.207 & 2.722 & 0.213 & 0.01 & 1.5 \\
\hline
\end{tabular}

The VOC concentrations are shown with standard deviations. The p-values were calculated by ANOVA. The ratio is a comparison of average concentrations of tumor-bearing mice and control mice 
tumor-bearing mice. The day of inoculation was defined as day 0 . The mice were kept in glass-shielded metabolic cages (Metabolica; Sugiyamagen, Tokyo, Japan) under sterile conditions and were supplied with radiation sterilized feed CE-2 (CLEA Japan, Tokyo Japan) and autoclaved drinking water, which was provided ad libitum. After transplantation, urine was collected from the mice daily, and stored at $-80^{\circ} \mathrm{C}$ until time of analysis. Body weight and tumor size (the shortest and longest diameters) of each mouse was recorded every few days. Tumor size was calculated by multiplying the length of the shortest and longest diameters. The mice were sacrificed 30 days after transplantation. The urine samples were collected from 26 to 30 days after transplantation.

All animals were treated in accordance with the institutional guidelines for the care and use of laboratory animals.

\section{Extraction of VOCs by headspace solid-phase microextraction}

Prior to the analysis of the urine and culture medium, we sought to determine the optimal suitable SPME fiber. Four types of SPME fibers (carboxen/polydimethylsiloxane: CAR/PDMS, divinylbenzene/carboxen/ polydimethylsiloxane: DVB/CAR/PDMS, polydimethylsiloxane/divinylbenzene: PDMS/DVB, Polyacrylate) were compared with the chromatogram obtained from the analysis of urine samples. The results of this analysis,

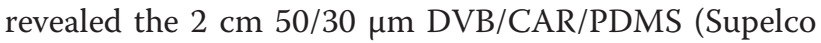
Corp, Bellefonte, PA, USA) fiber to be the optimal and this fiber was used for subsequent analyses. The urine and cell culture medium were centrifuged at 10,000 $\mathrm{g}$ for $5 \mathrm{~min}$ and, the supernatant was used for the analysis. The VOCs from urine and cell culture medium were extracted by HS-SPME methods using of Combi-pal auto sampler (CTC Analytics, Switzerland). A $200 \mathrm{~mL}$ sample of the urine or culture medium was applied to a $2 \mathrm{~mL}$ crimp top vial and sealed by crimp cap. The vial was set on Combi-pal and equilibrated for $10 \mathrm{~min}$ at $45^{\circ}$ C. The volatile compounds in the headspace were extracted by SPME fiber for $50 \mathrm{~min}$ at $45^{\circ} \mathrm{C}$.

\section{Gas chromatography and mass spectrometry}

The GC-TOF MS system was composed of a 7890a GC (Agilent, CA, USA) equipped with an auto sampler Combi-pal and GCT Premier (Waters, MA, USA) for time of flight mass spectrometry. The SPME fiber with absorbed volatile compounds was inserted into the injection port of the 7890a GC using the auto sampler and desorbed for $10 \mathrm{~min}$ at $240^{\circ} \mathrm{C}$. The injection was pulsed splitless (closed $3 \mathrm{~min}$ ) with a $0.75 \mathrm{~mm}$ liner. The GC-TOF MS system was equipped with an InertCap Pure-WAX T.L. column $(60 \mathrm{~m}+2 \mathrm{~m}$ transfer line, $0.25 \mathrm{~mm}$ i.d., $0.5 \mu \mathrm{m}$ thick; GL science, Japan), which was used for separation and analysis of the desorbed volatiles. We employed the following chromatographic protocol for separation before MS analyses: $40^{\circ} \mathrm{C}$ for 5 min, then programmed at $3^{\circ} \mathrm{C} / \mathrm{min}$ to $240^{\circ} \mathrm{C}$ with a 5 min hold at this final temperature. Column flow was constant at rate of $1 \mathrm{ml} / \mathrm{min}$. The injection port was held at $240^{\circ} \mathrm{C}$. Operating parameters for the mass spectrometer were as follows: the ion source temperature was $200^{\circ} \mathrm{C}$, ionizing energy at $70 \mathrm{eV}$, scanning frequency was $0.2 \mathrm{~s} /$ spectrum from $\mathrm{m} / z 40$ to $\mathrm{m} / z 500$. Peak identification was accomplished through manual interpretation of spectra and matching against the mass spectral library (NIST/EPA/NIH mass spectral library (NIST 08); mass spectral library of drugs, poisons, pesticides, pollutants and their metabolites Wiley, USA) and comparison with commercially available standard samples, which were purchased from the Tokyo Chemical Industry (Tokyo, Japan). Each medium sample was analyzed in triplicate.

\section{Data processing and quantitative analysis}

The chromatographic peak areas were integrated using the MassLynx 4.1 (Waters, MA, USA). Genesis peak detection was applied for a list of putatively annotated ions. Detection and integration of generated ion peak from electron ionization were also performed using a XCMS software package version 1.16.3 (http://masspec. scripps.edu) [33], running under $\mathrm{R}$ version 2.10 .1 (http://cran.r-project.org/). The significance levels of differences between groups were calculated using a student's $t$-test that come with XCMS software. We also determined that the "increased extracted ion peaks" had a $p$-value of $<0.10$, and were 1.5 times higher than the averaged peak area of the other group. Of those peaks, a manual inspection of the EIC for each peak was made to validate the detected peak. Refine the VOC was performed by manual deconvolution based on retention time and peak shape of each increased extracted ion peak.

The identified VOCs were quantified using commercially available reagents. For each of the reagents, stock solutions were made to a concentration of $100 \mathrm{mM}$ (Sigma-Aldrich, MI, USA) by dissolving them into $1 \mathrm{~mL}$ mixture of water and methanol $(1 / 1 \mathrm{v} / \mathrm{v})$. Calibration solutions of $0.01,0.02,0.05,0.1,0.5,1.0$, and $10.0 \mu \mathrm{M}$ were also made up. The standard curves were created based on the peak areas, which were obtained from HSSPME GC-TOF MS analysis of the calibration solution. The data were analyzed in triplicate. The $p$-values were obtained using ANOVA.

\section{Abbreviations}

VOCs: volatile organic compounds; COPD: chronic obstructive lung disease; TIC: total ion chromatogram; HS-SPME: headspace solid-phase 
microextraction; GC-TOF MS: gas chromatography time-of-flight mass spectrometry; DVB/CAR/PDMS: divinylbenzene/carboxen/

polydimethylsiloxane; CAR/PDMS: carboxen/polydimethylsiloxane; PDMS/

DVB: polydimethylsiloxane/divinylbenzene

\section{Acknowledgements}

This research is supported by the Japan Society for the Promotion of Science (JSPS) through its "Funding Program for World-Leading Innovative R\&D on Science and Technology (FIRST Program)".

\section{Author details}

${ }^{1}$ FRIST Research Center for Innovative Nanobiodevice, Nagoya University, Nagoya 464-8603, Japan. Bioscience Technology Development Office, Panasonic Corporation, Kyoto 619-0237, Japan. ${ }^{3}$ Department of Applied Chemistry, Graduate School of Engineering, Nagoya University, Nagoya 464 8603, Japan. ${ }^{4}$ Monell Chemical Senses Center, Philadelphia, PA 19104-3308, USA.

\section{Authors' contributions}

$\mathrm{YH}$ carried out the experiments and participated in the design of the study. KS advised in the study design and helped to draft the manuscript. YB helped to draft the manuscript. $\mathrm{HO}, \mathrm{KY}$, and GKB conceived of the study, participated in its design and coordination, and helped to draft the manuscript. All authors read and approved the final manuscript.

\section{Competing interests}

The authors declare that they have no competing interests.

Received: 7 September 2011 Accepted: 24 February 2012 Published: 24 February 2012

\section{References}

1. World Health Organization. Cancer, Factsheet N 297. [http://www.who. int/mediacentre/factsheets/fs297/en/], Last updated February 2011.

2. Ludwig JA, Weinstein JN: Biomarkers in cancer staging, prognosis and treatment selection. Nat Rev Cancer 2005, 5:845-856.

3. Brock MV, Hooker CM, Ota-Machida E, Han Y, Guo M, Ames S, Glöckner S, Piantadosi S, Gabrielson E, Pridham G, Pelosky K, Belinsky SA, Yang SC, Baylin SB, Herman JG: DNA methylation markers and early recurrence in stage I lung cancer. N Engl J Med 2008, 358:1118-1128.

4. Sawyers CL: The cancer biomarker problem. Nature 2008, 452:548-552.

5. Greenberg AK, Lee MS: Biomarkers for lung cancer: clinical uses. Curr Opin Pulm Med 2007, 13:249-255.

6. In Breath Analysis for Clinical Diagnosis and Therapeutic Monitoring. Edited by: Amann A, Smith D. Singapore: World Scientific; 2005:

7. Amann A, Spanel P, Smith D: Breath analysis: the approach towards clinical applications. Mini-Rev Med Chem 2007, 7:115-129.

8. Schubert J, Miekisch W, Noldge-Schomburg G: VOC breath markers in critically ill patients: potentials and limitations. In Breath Analysis for Clinical Diagnosis and Therapeutic Monitoring. Edited by: Amann A, Smith D. Singapore: World Scientific; 2005:267-292.

9. Risby T, Amann A, Smith D: Current status of clinical breath analysis. Breath Analysis for Clinical Diagnosis and Therapeutic Monitoring Singapore: World Scientific; 2005, 251-265.

10. Chen CP, Chen CY, Lu CL, Chang FY, Lee SD, Chu LS, Liu RS, Wu HC: Infrared spectrometry based 13 C-octanoic acid breath test in measuring human solid gastric emptying. J Gastroenterol Hepatol 2003, 18:41-46.

11. Liao CC, Lee CL, Chiang TC, Lee SC, Huang SH, Tu TC, Chen TK, Wu CH: The $13 \mathrm{C}$-urea breath test to detect Helicobacter pylori infection: a validated simple methodology with 50 mg 13C-urea. Aliment Pharmacol Ther 2002, 16:787-792.

12. Eisenmann A, Amann A, Said M, Datta B, Ledochowski M: Implementation and interpretation of hydrogen breath test. J Breath Res 2008, 2(4):046002.

13. Lebovitz HE: Diabetic ketoacidosis. Lancet 1995, 345:767-772

14. Chen S, Zieve L, Mahadevan V: Mercaptans and dimethyl sulfide in the breath of patients with cirrhosis of the liver. Effect of feeding methionine. J Lab Clin Med 1970, 75:628-635.
15. Simenhoff ML, Burke JF, Saukkonen JJ, Ordinario AT, Doty R: Biochemical profile or uremic breath. N Engl J Med 1977, 297:132-135.

16. Aghdassi $E$, Allard JP: Breath alkanes as a marker of oxidative stress in different clinical conditions. Free Radic Biol Med 2000, 28:880-886.

17. Pabst F, Miekisch W, Fuchs P, Kischkel S, Schubert JK: Monitoring of oxidative and metabolic stress during cardiac surgery by means of breath biomarkers: an observational study. J Cardiothorac Surg 2007, 2:37.

18. Phillips M, Altorki N, Austin JH, Cameron RB, Cataneo RN, Greenberg J, Kloss R, Maxfield RA, Munawar Ml, Pass HI, Rashid A, Rom WN, Schmitt P: Prediction of lung cancer using volatile biomarkers in breath. Cancer Biomarkers 2007, 3:95-109.

19. Phillips M, Cataneo RN, Cummin AR, Gagliardi AJ, Gleeson K, Greenberg J, Maxfield RA, Rom WN: Detection of lung cancer with volatile markers in the breath. Chest 2003, 123:2115-2123.

20. Wehinger A, Schmid A, Mechtcheriakov S, Ledochowski M, Grabmer C, Gastl GA, Amann A: Lung cancer detection by proton transfer reaction mass spectrometric analysis of human breath gas. Int J Mass Spectrom 2007, 265:49-59.

21. Machado RF, Laskowski D, Deffenderfer O, Burch T, Zheng S, Mazzone PJ, Mekhail T, Jennings C, Stoller JK, Pyle J, Duncan J, Dweik RA, Erzurum SC: Detection of lung cancer by sensor array analyses of exhaled breath. Am J Respir Crit Care Med 2005, 171:1286-1291.

22. Di Natale C, Macagnano A, Martinelli E, Paolesse R, D'Arcangelo G, Roscioni C, Finazzi-Agrò A, D'Amico A: Lung cancer identification by the analysis of breath by means of an array of non-selective gas sensors. Biosens Bioelectron 2003, 18:1209-1218.

23. Poli D, Carbognani P, Corradi M, Goldoni M, Acampa O, Balbi B, Bianchi L, Rusca M, Mutti A: Exhaled volatile organic compounds in patients with non-small cell lung cancer: cross sectional and nested short-term followup study. Respir Res 2005, 6:71.

24. Ligor M, Ligor T, Bajtarevic A, Ager C, Pienz M, Klieber M, Denz H, Fiegl M, Hilbe W, Weiss W, Lukas P, Jamnig H, Hackl M, Buszewski B, Miekisch W Schubert J, Amann A: Determination of volatile organic compounds appearing in exhaled breath of lung cancer patients by solid phase microextraction and gas chromatography mass spectrometry. Clin Chem Lab Med 2009, 47:550-560.

25. Chen X, Xu F, Wang Y, Pan Y, Lu D, Wang P, Ying K, Chen E, Zhang W: A study of the volatile organic compounds exhaled by lung cancer cells in Vitro for breath diagnosis. Cancer 2007, 110:835-844.

26. Dragonieri S, Annema JT, Schot R, van der Schee MP, Spanevello A, Carratú P, Resta O, Rabe KF, Sterk PJ: An electronic nose in the discrimination of patients with non-small cell lung cancer and COPD Lung Cancer 2009, 64:166-170.

27. Willis CM, Church SM, Guest CM, Cook WA, McCarthy N, Bransbury AJ, Church MR, Church JC: Olfactory detection of human bladder cancer by dogs: proof of principle study. British Med J 2004, 329:712.

28. Gordon RT, Schatz CB, Myers LJ, Kosty M, Gonczy C, Kroener J, Tran M, Kurtzhals P, Heath S, Koziol JA, Arthur N, Gabriel M, Hemping J, Hemping G, Nesbitt S, Tucker-Clark L, Zaayer J: The use of canines in the detection of human cancers. J Alter Compl Med 2008, 14:61-67.

29. Matsumura K, Opiekun M, Oka H, Vachani A, Albelda SM, Yamazaki K, Beauchamp GK: Urinary volatile compounds as biomarkers for lung cancer: a proof of principle study using odor signatures in mouse models of lung cancer. PLoS One 2010, 5(1):e8819.

30. Smith D, Wang TS, Sule-Suso J, Spanel P, El Haj A: Quantification of acetaldehyde released by lung cancer cells in vitro using selected ion flow tube mass spectrometry. Rapid Comm Mass Spectrom 2003, 17:845-850.

31. Filipiak W, Sponring A, Mikoviny T, Ager C, Schubert J, Miekisch W, Amann A, Troppmair J: Release of volatile organic compounds (VOCs) from the lung cancer cell line CALU-1 in vitro. Canc Cell Int/ 2008, 8:17.

32. Sponring A, Filipiak W, Mikoviny T, Ager C, Schubert J, Miekisch W, Amann A, Troppmair J: Release of volatile organic compounds from the lung cancer cell line NCl-H2087 in vitro. Anticancer Res 2009, 29:419-426.

33. Smith CA, Want EJ, O'Maille G, Abagyan R, Sizudak G: XCMS: Processing Mass Spectrometry Data for Metabolite Profiling Using Nonlinear Peak Alignment, Matching, and Identification. Anal Chem 2006, 78:779-787.

34. Filipiak W, Sponring A, Filipiak A, Ager C, Schubert J, Miekisch W, Amann A, Troppmair J: TD-GC-MS Analysis of Volatile Metabolites of Human Lung Cancer and Normal Cells In vitro. Canc Epidemiol Biomarkers Prev 2010, 19:182-195. 
35. O'Nell HJ, Gordon SM, O'Nell MH, Glbbons RD, Szldon JP: A computerized classification technique for screening for the presence of breath biomarkers in lung cancer. Clin Chem 1988, 34/8:1613-1618.

36. Kusuhara M, Urakami K, Zangicomi V, Hoshino K: Disease and smell: "Byoshu". Anti-Aging Med 2010, 7(6):66-72

doi:10.1186/1475-2867-12-7

Cite this article as: Hanai et al: Analysis of volatile organic compounds released from human lung cancer cells and from the urine of tumorbearing mice. Cancer Cell International 2012 12:7.

Submit your next manuscript to BioMed Central and take full advantage of:

- Convenient online submission

- Thorough peer review

- No space constraints or color figure charges

- Immediate publication on acceptance

- Inclusion in PubMed, CAS, Scopus and Google Scholar

- Research which is freely available for redistribution

Submit your manuscript at www.biomedcentral.com/submit 